\title{
生活習慣病を標的とした分子疫学コホート研究の展望
}

\author{
今井 博久 ${ }^{* 1}$, 塩飽 邦憲 ${ }^{* 2}$ \\ ${ }^{* 1}$ 国立保健医療科学院疫学部 \\ ${ }^{* 2}$ 島根大学医学部環境保健医学講座
}

\section{Perspective for Molecular Epidemiologic Cohort Study of Lifestyle-Related Disease}

\author{
Hirohisa IMAI ${ }^{* 1}$ and Kuninori SHIWAKU*2 \\ ${ }^{*}$ Department of Epidemiology, National Institute of Public Health \\ ${ }^{*}$ Department of Environmental \& Preventive Medicine, Shimane University School of Medicine
}

\begin{abstract}
The 80th annual meeting of the Japanese Society of Hygiene was held this year in Sendai. The authors hosted a symposium entitled "Perspective for molecular epidemiologic cohort study of lifestylerelated disease," at which four guests served as panelists. Through the courtesy of Editor-in-Chief Dr. Ohtsuki, space in the current issue has been devoted to a "mini feature" on the symposium to provide briefings by two panelists, Dr. Kurokawa and Dr. Hata. Here, the authors provide an introduction to the briefings, describe the current status of research and state their expectations for the future.
\end{abstract}

Key words：lifestyle-related disease（生活習慣病）, molecular epidemiology（分子疫学), cohort study（コホート研究）

\section{はじめに}

本年度（平成 22 年度）の第 80 回日本衛生学会学術総 会が東北大学の佐藤洋教授により仙台市で開催された。 筆者らによるシンポジウム「生活習慣病を標的とした分 子疫学コホート研究の展望」が行われ, 四人のパネリス トが報告した（1）。大槻剛已編集委員長のご厚意により 本誌今号の誌面の一部を「ミニ特集」の形で使わせてい ただき，シンポジウムの報告内容を演者の二人，黒川修 行博士と秦淳博士から解説してもらら。ここでは, それ らの解説文の前口上として現状と今後に向けた期待を述 ベたい。

シンポジゥムを企画した趣旨として, 近年, 社会医学 系の研究者が中心となり全国各地で生活習慣病を標的と

受付 2010 年 12 月 12 日, 受理 2010 年 12 月 13 日

Reprint requests to: Hirohisa IMAI

Department of Epidemiology, National Institute of Public Health, 2-36 Minami, Wako, Saitama 351-0197, Japan

TEL: +81(48)458-6167, FAX: +81(48)469-2677

E-mail: imaihiro@niph.go.jp
した遺伝子多型を含む疫学コホート研究（分子疫学コ ホート研究）が積極的に展開され，たとえば久山町研究 を始めとして原因遺伝子多型に関する多くの成果が挙 がってきている背景がある。また社会医学系の研究者の 久ならず臨床医学研究者や基礎医学研究者を含めて多く の研究者が生活習慣病を標的とした遺伝子多型を含む分 子疫学コホート研究の重要性を認識しつつあり, 多様な 研究者が集う衛生学会の学術集会で本テーマを掲げたシ ンポジゥムは，時宜を得た試みとして大きな意義があっ たと言えよう。

\section{最近の動向}

先進諸国では，人々を取り巻く環境要因の均質化に 伴って生活習慣病における遺伝要因の重要性が増してい る。一方, 分子生物学が飛躍的に発展し, それを応用し た技術革新も進み DNA マイクロアレイや次世代シーク エンサーによって大量に一塩基多型の判定が迅速に実施 できるようになった。こうした技術革新が長足の進歩を 遂げる中, 近年, 生活習慣病関連遺伝子の同定研究が急 
速に発展し, とりわけゲノムワイド研究を軸とした遺伝 子一環境相互作用や遺伝子間相互作用の研究が米国や欧 州で盛んに進められている。

今後に向けた主要な課題は，この研究分野から生み出 される研究成果をどのように活用して行くかであろら。 最近，広く人口に膾多している「オーダーメイド医療」 はこれらの研究成果を活用する試みであり，臨床医学分 野に打ける薬物遺伝学的検査で重要な役割を果たしつつ ある。しかしながら，実際のところ，未だに日常臨床場 面でルーチンに利用される状況には至っていない。同様 に唱えられている「オーダーメイド予防」に関しても研 究段階の成果報告さえなく, 今後の予防医学分野からの 報告に期待したい。

\section{生活習慣病における環境要因と遺伝要因}

糖尿病，高血圧，肥満，心臓病，脳卒中，悪性腫瘍な どの疾患はかつて「成人病」と呼ばれていたが，契煙， 飲酒, 運動, 食事などの生活習慣, すなわち生活環境要 因がその発症や進行に深く関与していることが多くの疫 学研究や臨床研究により明らかになっており, 現在は「生 活習慣病」といら表現に改められている。これらの疾患 は生活習慣の改善により疾患の発症抑制や進行予防が一 定の程度可能となる $(2,3)$ 。

一方，双生児や家族歴を用いた疫学研究により，生活 習慣病の多くは遺伝的要因を有することが指摘されてい る (4-6)。家系内の単一遺伝子の突然変異に起因し優性 遺伝もしくは劣性遺伝の形式で発症するメンデル型遺伝 病とは異なり, 生活習慣病の原因遺伝子は一般に複数存 在すると考光られて打り, 個々の遺伝子の変化の影響は 比較的小さいと考えられている。また，疾患にかかりや すい遺伝子型を保因していたとしても，生活習慣や環境 によってはその疾患にかかるとは限らない。すなわち， 生活習慣病は複数の遺伝的要因に多数の生活習慣 - 環境 要因が複雑に組み合わさることによって発症する「多因 子疾患」と考㝋られている。

\section{生活習慣病と一塩基多型（SNPs）}

生活習慣病のように頻度の高い疾患では，その原因と なるゲノム上の変化は家系が異っていても共通のものが 多く (common disease common variant 仮説)，この変化は 集団内に比較的高い頻度で保存されていると考えられて いる。そこで，近年，生活習慣病の遺伝要因として遺伝 子多型が注目されている。遺伝子多型とは, ゲノム上の 塩基配列の変化が集団内に $1 \%$ 以上の頻度でみられる ものとされており, 一塩基多型 (SNP, single nucleotide polymorphism, 1 つの塩基が他の塩基に置き換わっている もの), VNTR (valuable number of tandem repeat, 数塩基 〜数十塩基の配列の繰り返し回数が異なっているもの), マイクロサテライト（2４ 塩基程度の配列の繰り返し
回数が異なっているもの), 挿入欠失多型（塩基配列の一 部が挿入されるか欠失しているもの）などに分類されて いる。この中で，SNPはゲノム全体に渡って高頻度に分 布しているため連鎖不平衡解析による候補遺伝子領域の 絞込みに適していること, 遺伝子産物（蛋白）のアミ， 酸配列や発現量を変化させる可能性があり分子生物学的 に意義の高い多型であることから，生活習慣病の遺伝要 因として特に注目されている。

\section{生活習慣病関連遺伝子の同定方法}

生活習慣病の関連遺伝子の同定方法は，候補遺伝子研 究とゲノムワイド研究の 2 つに大別される。

候補遺伝子研究は，対象疾患の病態への関与が考兄ら れる既知の遺伝子に着目し，対象疾患の患者群と対照群 の間でその遺伝子多型の頻度を比較することにより疾患 関連遺伝子を同定するものであり，比較的古くから採用 されていた方法である。本特集では，黒川らが肥満の関 連遺伝子としてアドレナリン受容体遺伝子（ADRB3）の メタアナリシスの結果を紹介しているが，この遺伝子に 着目した理由はアドレナリンが脂肪代謝や基礎代謝の調 整に関係するからである。

ゲノムワイド研究は，機能的な候補を想定することな く，疾患と遺伝子多型の相関の強い領域をゲノム全体に わたって網羅的に探索するものである。従って，既知の 病態生理学的機序からは予測出来なかったよらな新規の 関連遺伝子領域の同定が可能となる。2001 年にヒトゲノ ムの塩基配列の全貌が明らかとされたことを契機に，ヒ トゲノムに無数に存在する遺伝子多型を同定しデータ ベース化するためのプロジェクトが立ち上がった。わが 国では，日本人を対象とした SNP のデータベースである $\operatorname{JSNP}(7)$ が良く知られている。本特集では，秦らが理化 学研究所と同様の方法を用いて脳梗塞のゲノムワイド関 連研究を実施し, 3 つ新規関連遺伝子を紹介している。

\section{遺伝子一環境相互作用と遺伝子一遺伝子相互作用}

近年のゲノムワイド研究により, 既知の病理生理学的 機序からはほとんぞ予測出来なかったよらな新規の生活 習慣病関連遺伝子が続々と同定されるようになってい る。しかし，実際の臨床や公衆衛生の場面でその恩恵が 十分得られるよらになるまでにはまだ多数の課題があ る。個別の遺伝子多型がもたらす遺伝的効果は非常にマ イルドであり，遺伝子多型の解析のみでは疾患のメカニ ズムを十分説明できないからである。

関連遺伝子の発現やその遺伝子産物の機能は，それを 取り巻く環境の変化によって巧妙に調整されている（遺 伝子一環境相互作用，gene-environment interaction）。ま た，個々の遺伝子は独立して機能しているのではなく， 他の遺伝子の影響を受けて緻密に調整されている（遺伝 子間相互作用， gene-gene interaction）。従って，遺伝子多 
型が疾患に及ぼす影響をより明確に理解するためには， これらの複雑な相互作用を把握する必要があり, それを 実現するためには多くの様々な研究手法（高度な統計学 等）と成果（環境要因の測定やコホート研究）が必要で あると考えられる。

ゲノムワイド研究を基軸とした遺伝子一環境相互作用 や遺伝子間相互作用の探求は，現在欧米を中心に精力的 に進められつつある。本邦では，2003 年より文部科学省 リーディングプロジェクトとして，47 の疾患を対象とし た「オーダーメイド医療実現化プロジェクト」が進行中 である。今回のシンポジウムで報告した国立国際医療研 究センターの加藤規弘部長らのグループでは, 日本, ス リランカ, ベトナムの各施設の協力を得て, 約 5 万人を 対象としたネットワークを組織し，生活習慣病を対象と したゲノムワイド解析に基づく大規模ゲノム疫学コホー 卜研究を進めて扣り，その結果に大きな期待が寄せられ ている。

\section{遺伝子多型に基づくオーダーメイド予防}

生活習慣病の関連遺伝子が同定され，さらにその背景 にある環境一遺伝子相互作用や遺伝子間相互作用が明ら かとなることにより，いくつかの効果が期待される。ま ず，疾患を発症するメカニズムが分子レベルで解明され るため，その疾患の検査法や治療法の新たな開発に結び つけることが期待できる（オーダーメイド医療）。また， 遺伝子多型を用いて疾患の発症のリスクを予測すること が可能となり，遺伝子多型のタイプを判定して個人毎の 遺伝的体質に合わせた保健指導が可能となるだろら。

有馬らは，久山町の前向きコホート研究のデータを用 いて，心血管病の発症を予測するためにリスクスコアを 開発した (8)。このリスクスコアに含まれている変数は, 性, 年齢, 血圧, 糖尿病, 脂質, 喫煙といった古典的な 心血管病危険因子のみであるが，今後，これらの危険因 子と脳梗塞関連遺伝子の相互作用が明らかになれば, SNPを考慮した脳梗塞のリスクスコアを作成することが 可能となり, より精度の高い脳梗塞の発症予測が可能と なるかもしれない。

今井らは, 今回のシンポジゥムの中で, 候補遺伝子研 究で既に同定された肥満関連遺伝子，インスリン抵抗性 関連遺伝子の複数のSNP を活用して糖尿病予備群に対 する保健指導介入のパイロット研究の一部を報告した $(9,10)$ 。一般住民を対象に，SNP を判定した結果を用い た保健指導介入群と, SNPを用いない従来型の保健指導 群の 2 群に無作為に割付け, その後の体重変化や他の生 活習慣病関連項目を比較検討した。その結果, 介入群で は従来指導群と比べ有意な体重減少が認められ，血圧， 血糖, 脂質值も明らかに改善した。このように，SNP に 基づく保健指導が一定の効果を挙げる可能性が期待さ れ，今後，実用的な方法論の早期確立が待たれる。

\section{おわりに}

生活習慣病を標的とした分子疫学コホート研究がます ます盛んになり，研究成果が臨床分野や予防分野で具体 的に活用され「オーダーメイド医療」や「オーダーメイ ド予防」として実際に役立つ医療技術にすることが，社 会医学系の研究者が担当すべき責務であり，将来に向け て若い研究者が担って行かなければならない使命であ る。こうした研究の成果が，病に苦しむ患者や危険因子 を持つ予備群の人々に多くの福音がもたらされることを 期待したい。今後のさらなる研究推進が望まれる。

\section{文献}

（1）生活習慣病を標的とした分子疫学コホート研究の展 望. 日本衛生学会誌 $2010 ; 65: 198-204$.

(2) Tuomilehto J, Lindström J, Eriksson JG, Valle TT, Hämäläinen H, Ilanne-Parikka P, Keinänen-Kiukaanniemi S, Laakso M, Louheranta A, Rastas M, Salminen V, Uusitupa M; Finnish Diabetes Prevention Study Group. Prevention of type 2 diabetes mellitus by changes in lifestyle among subjects with impaired glucose tolerance. N Engl J Med. 2001; 344:1343-1350.

(3) Lindström J, Ilanne-Parikka P, Peltonen M, Aunola S, Eriksson JG, Hemiö K, Hämäläinen $\mathrm{H}$, Härkönen $\mathrm{P}$, Keinänen-Kiukaanniemi S, Laakso M, Louheranta A, Mannelin M, Paturi M, Sundvall J, Valle TT, Uusitupa M, Tuomilehto J; Finnish Diabetes Prevention Study Group. Sustained reduction in the incidence of type 2 diabetes by lifestyle intervention: follow-up of the Finnish Diabetes Prevention Study. Lancet. 2006;368:1673-1679.

(4) McNeill G, Tuya C, Smith WC. The role of genetic and environmental factors in the association between birthweight and blood pressure: evidence from meta-analysis of twin studies. Int J Epidemiol. 2004;33: 995-1001.

( 5 ) Silventoinen K, Rokholm B, Kaprio J, Sørensen TI. The genetic and environmental influences on childhood obesity: a systematic review of twin and adoption studies. Int $\mathrm{J}$ Obes. 2010;34:29-40.

(6) Floßmann E, Schulz UGR, Rothwell PM. Systematic review of methods and results of studies of the genetic epidemiology of ischemic stroke. Stroke. 2004;35:212-227.

( 7 ) Hirakawa M, Tanaka T, Hashimoto Y, Kuroda M, Takagi T, Nakamura Y. JSNP: a database of common gene variations in the Japanese population. Nucleic Acids Res. 2002; $30: 158-162$.

( 8 ) Arima H, Yonemoto $\mathrm{K}$, Doi $\mathrm{Y}$, Ninomiya $\mathrm{T}$, Hata $\mathrm{J}$, Tanizaki Y, Fukuhara M, Matsumura K, Iida M, Kiyohara Y. Development and validation of a cardiovascular risk prediction model for Japanese: the Hisayama study. Hypertens Res. 2009;32:1119-1122.

（9）中尾裕之, 今井博久, 佐田文宏, 福田吉治, 松久宗英, 山崎義光. 糖尿病予備群に対寸る分子予防疫学的アプ ローチーオーダーメイド栄養・運動指導の試み一. 肥 満と糖尿病 2009;8:82-85.

（10）山崎義光，片上直人，今井博久. 生活習慣病に対する 遺伝子検查. 総合健診 2010;37:246-252. 